\title{
Meningkatkan Kinerja Guru-Guru dalam Melaksanakan Proses Pembelajaran dengan Menerapkan Model Pembelajaran Kooperatif Tipe Student Team Achievement Devision (STAD) dan Supervisi Akademik
}

\section{Putu Ciri Bagiani*}

SD Negeri 1 Temesi, Gianyar, Indonesia

\section{A R T I C L E I N F O}

\section{Article history:}

Received 19 August 2020

Received in revised form 30 September 2020 Accepted 10 October 2020

Available online 29

November 2020

Kata Kunci:

Supervisi Akademik,

Pembelajara Student Team

Achievement Devision

(STAD), Kemampuan Guru

Keywords:

Academic Supervision

Student Team Achievement

Devision (STAD) Learning,

Teacher Ability

A B S T R A K

Penelitian Tindakan ini bertujuan untuk meningkatkan Kinerja Guru SD dalam melaksanakan proses pembelajaran. Data hasil penelitian ini dikumpulkan dengan cara obserpasi Kelas/Kunjungan kelas dengan instrumen. Dalam menganalisis data yang diperoleh digunakan metode analisis deskriptif. Data yang dihasilkan dari penelitian ini terdiri dari data awal, data siklus I dan data Siklus II. Dari data awal diperoleh rata-rata kemampuan melaksanakan proses pembelajaran, baru mencapai nilai 75,00 dan ketuntasan baru mencapai $55,55 \%$. Data ini jauh di bawah harapan mengingat Ketuntasan pelaksanaan Proses Pembelajaran minimal 86,00. Rata-rata nilai siklus I sudah terjadi peningkatan yaitu rata-ratanya mencapai 83,33 dan prosentase ketuntasannya mencapai $77,77 \%$. Pada siklus II perolehan rata-ratanya sudah mencapai 91,44 dan persentase ketuntasan sudah mencapai $100 \%$. Data pada Siklus II ini sudah sesuai harapan, dengan melaksanakan proses Pembelajaran mengikuti alur pembelajaran Student Team Achievement Devision (STAD), dapat meningkatkan kinerja guru melaksanakan proses pembelajaran. Jadi, dengan adanya model STAD dapat meningkatkan kinerja guru melaksanakan pemebalajaran.

\section{A B S T R A C T}

This action research aims to improve the performance of elementary school teachers in carrying out the learning process. The data from the research results were collected by observing the class / class visits with the instrument. In analyzing the data obtained used descriptive analysis method. The data generated from this study consisted of initial data, data from cycle I and data from cycle II. From the initial data, it is obtained that the average ability to carry out the learning process has only reached a value of 75,00 and new mastery has reached $55.55 \%$. This data is far below expectations considering the completeness of the implementation of the Learning Process is at least 86,00. The average value of the first cycle has increased, namely the average reached 83,33 and the percentage of completeness reached $77,77 \%$. In cycle II, the average score has reached 91,44 and the percentage of completeness has reached $100 \%$. The data in Cycle II is as expected, by implementing the Learning process following the Student Team Achievement Devision (STAD) learning path, it can improve teacher performance in implementing the learning process. So, with the STAD model it can improve teacher performance in implementing learning. 


\section{Pendahuluan}

Pendidikan nilai dibutuhkan sejak anak masih dini. Apabila kepribadian seseorang sudah terbentuk sejak usia dini, ketika dewasa tidak akan mudah berubah meski godaan atau rayuan datang begitu menggiurkan. Dengan adanya pendidikan nilai sejak usia dini, diharapkan persoalan mendasar dalam dunia pendidikan yang akhir-akhir ini sering menjadi keprihatinan bersama dapat diatasi. Pendidikan nilai dan pendidikan kewarganegaraan di Indonesia sangat diharapkan dapat mencetak alumni pendidikan yang unggul, yakni para anak bangsa yang beriman, bertakwa, berakhlak mulia, mempunyai keahlian dibidangnya, dan berkarakter warga negara yang baik (Sutrisno, 2016). Keberhasilan proses pembelajaran tidak terlepas dari bagaimana peran guru dalam proses pembelajaran.

Cara pembelajaran guru yang terus-menerus menggunakan model pembelajaran konvensional,. Kebiasaan guru mengajar dengan sistem lama hal ini sedanada dengan hasil supervisi yang dilkukan menunjukkan bahwa. Adanya suatu permasalahan yang kurang baik dan sudah terjadi berlarut-larut di SD Negeri 1 Temesi adalah rendahnya kemampuan guru untuk melaksanakan proses pembelajaran sesuai hasil supervisi yang dilakukan sebelumnya yaitu baru mencapai rata-rata 78,66. Jika maslah ini dibirkan akan banyak hal yang dirugikan tentunya secara tidak langsung hasil dari proses pendidikan pun akan dipengaruhi. Oleh sebab itulah guru-guru harus berupaya melakukan pembelajaran menggunakan modelmodel pembelajaran yang didasari teori-teori yang benar serta peranan kepala sekolah sangat dibutuhkan dalam hal ini.

Tugas utama seorang kepala sekolah adalah mengawasi dan sekaligus meningkatkan kemampuan guru dalam melaksanakan proses pembelajaran (Hadi, 2019; Widiyastuti \& Arikunto, 2015). Sebagai kepala sekolah harus betul-betul memperhatikan apakah pembelajaran itu berkualitas atau tidak, apabila tidak berkualitas maka hal tersebut akan berbahaya terhadap mutu pendidikan. Oleh karenanya sebagai seorang Kepala Sekolah mesti giat untuk melakukan supervisi. Supervisi akademik menitik beratkan pengamatan pada masalah yang langsung berada dalam lingkup pembelajaran yang dilakukan guru untuk membantu siswa ketika sedang dalam proses belajar sehingga semakin sering kepala sekolah melakukan supervisi akademik, maka akan terdapat peningkatan secara signifikan kualitas kinerja guru dalam proses pembelajaran (Hadi, 2019).

Penelitian tentang supervisi sudah banyak dilakukan, seperti yang dilakukan oleh (Karsiyem \& Wangid, 2015) dengan judul Pelaksanaan Supervisi Akademik Dalam Peningkatan Kinerja Guru Sekolah Dasar Gugus III Sentolo Kulon Progo. Hasil penelitian: menunjukkan bahwa: (a) supervisi akademik meliputi perencanaan pembelajaran, pelaksanaan pembelajaran, dan penilaian pembelajaran; (b) prinsipprinsip supervisi akademik meliputi: praktis, objektif, humanis, kooperatif, keke-luargaan, demokratis, komprehensif, prinsip berkesimbungan belum dilaksanakan, teknik dalam supervisi invidual dan kelompok; (c) tindak lanjut supervisi belum dilakukan dengan optimal, (d) pendukung supervisi kesediaan guru disupervisi, jadwal, seprofesi, kendala supervisi guru terbebani dan banyaknya kegiatan kepala sekolah; (e) upaya memberikan pemahaman supervisi akademik sebagai kebutuhan guru dan jadwal supervisi efektif. Penelitian yang dilakukan oleh Suwartini (2017) dengan judul Supervisi Akademik Kepala Sekolah, Profesionalisme Guru Dan Mutu Pendidikan. Hasil penelitian menunjukkan bahwa: (1) Terdapat pengaruh positif dan signifikan supervisi akademik kepala sekolah terhadap mutu pendidikansebesar 30,9\%. Ini mengandung arti bahwa semakin baik supervisi akademik kepala sekolah maka akan semakinbaik pula mutu pendidikan (2) Terdapat pengaruh positif dan signifikan antara profesionalisme guru terhadap mutu pendidikan sebesar 20,2\%. Ini mengandung arti bahwa semakin baikprofesionalisme guru maka akan semakin baik mutu pendidikannya (3) Terdapat pengaruh positif dan signifikan secara bersama-sama antara supervisi akademik kepala sekolah dan profesionalismeguru terhadap mutu pendidikansekolah dasar negeri di Kabupaten Purwakarta sebesar 36,3\%. Mengandung arti bahwa semakin baik supervisi akademik kepala sekolah dan semakin baikprofesionalisme gurumaka semakin baik mutu pendidikan.

Seperti yang sudah dijabarakan sebelumnya guru juga harus memperhaikan model pembelajaran yang digunkan, salah satu model pembelajaran yang dilkukan adalah model pembelajaran STAD. STAD merupakah salah satu model pembelajaran yang berguna untuk menumbuhkan kemampuan kerjasama, kreatif, berpikir kritis dan ada kemampuan untuk membantu teman serta merupakan pembelajaran kooperatif yang sangat sederhana (HM, 2019; Israil, 2019; Purba, 2018). Langkah-langkan pembelajaran kooperatif tipe STAD menurut Slavin disajikan dalam tabel di bawah ini. 
Tabel 1. Langkah-langkah pembelajaran kooperatif tipe STAD menurut Slavin (2008: 8), yaitu:

\begin{tabular}{|c|c|c|}
\hline No & Langkah & Kegiatan \\
\hline 1 & $\begin{array}{l}\text { Menyampaikan tujuan } \\
\text { dan memotivasi siswa }\end{array}$ & $\begin{array}{l}\text { menyampaikan semua tujuan pelajaran yang ingin dicapai pada } \\
\text { pelajaran tersebut dan memotivasi siswa belajar }\end{array}$ \\
\hline 2 & Menyajikan informasi & $\begin{array}{l}\text { menyampaikan informasi kepada siswa dengan jalan demonstrasi } \\
\text { atau lewat bacaan }\end{array}$ \\
\hline 3 & $\begin{array}{l}\text { Mengorganisasikan } \\
\text { siswa ke dalam } \\
\text { kelompok }\end{array}$ & $\begin{array}{l}\text { menjelaskan kepada siswa bagaimana caranya membentuk } \\
\text { kelompok belajar dan membantu setiap kelompokagar melakukan } \\
\text { transisi secara efisien. }\end{array}$ \\
\hline 4 & $\begin{array}{l}\text { Membimbing kelompok } \\
\text { bekerja dan belajar }\end{array}$ & $\begin{array}{l}\text { membimbing kelompok-kelompok belajar } \\
\text { pada saat mereka mengerjakan tugas mereka }\end{array}$ \\
\hline 5 & Evaluasi & $\begin{array}{l}\text { Mengevaluasi hasil belajar tentang materi yang telah dipelajari } \\
\text { atau masing-masing kelompok mempresentasikan hasil } \\
\text { kerjanya. }\end{array}$ \\
\hline 6 & $\begin{array}{l}\text { Memberikan } \\
\text { penghargaan }\end{array}$ & $\begin{array}{l}\text { mencari cara untuk menghargai baik upaya maupun hasil belajar } \\
\text { individu dan kelompok. }\end{array}$ \\
\hline
\end{tabular}

Beberapa penelitian yang sudah dilakukan antara lain: Hasil penelitian yang dilakukan oleh (Darmayanti, 2018) dengan judul Pengaruh Model Pembelajaran STAD berbasis Portofolio terhadap Kompetensi Pengetahuan Matematika. Berdasarkan hasil penelitian dapat disimpulkan bahwa terdapat pengaruh model pembelajaran STAD berbasis portofolio terhadap kompetensi pengetahuan matematika pada siswa kelas V SD Negeri 1 Ubud tahun pelajaran 2017/2018. Berdasarkan hasil penelitian disarankan bahwa hasil penelitian ini dapat dijadikan sebagai kajian yang relevan khususnya sebagai penunjang penelitian selanjutnya mengenai model pembelajaran STAD berbasis portofolio. Selanjutnya penelitian yang dilakukan oleh (Sudana, 2017) dengan judul penerapan model pembelajaran kooperatif tipe STAD untuk meningkatkan hasil belajar IPA. Hasil penelitian menunjukkan bahwa penerapan model pembelajaran Tipe STAD dapat meningatkan hasil belajar IPA siswa kelas IV A semester ganjil Tahun Pelajaran 2016/2017 di SD No. 3 Dalung.

Berdasarkan jabaran tersebut maka dirumuskan sebuah tujuan penelitian yaitu untuk meningkatkan Kinerja Guru SD dalam melaksanakan proses pembelajaran dengan model kooperatif tipe STAD dan Supervisi akademik. Dengan penerapan kedau hal ini diharapakan masalah kinerja guru dalam prose pembelajaran bisa dikurangi, bahkan bisa dihentikan sehingga kualitas pembelajaran tercapai.

\section{Metode}

Penelitian yang dilakukan termasuk jenis penelitian tindakan. Penelitian tindakan ini terfokus pada penelitian tindakan sekolah. Salah satu contoh penelitian tindakan adalah desain yang dibuat oleh Ebbut dalam (Sukidin et al., 2002) seperti terlihat pada gambar berikut. 


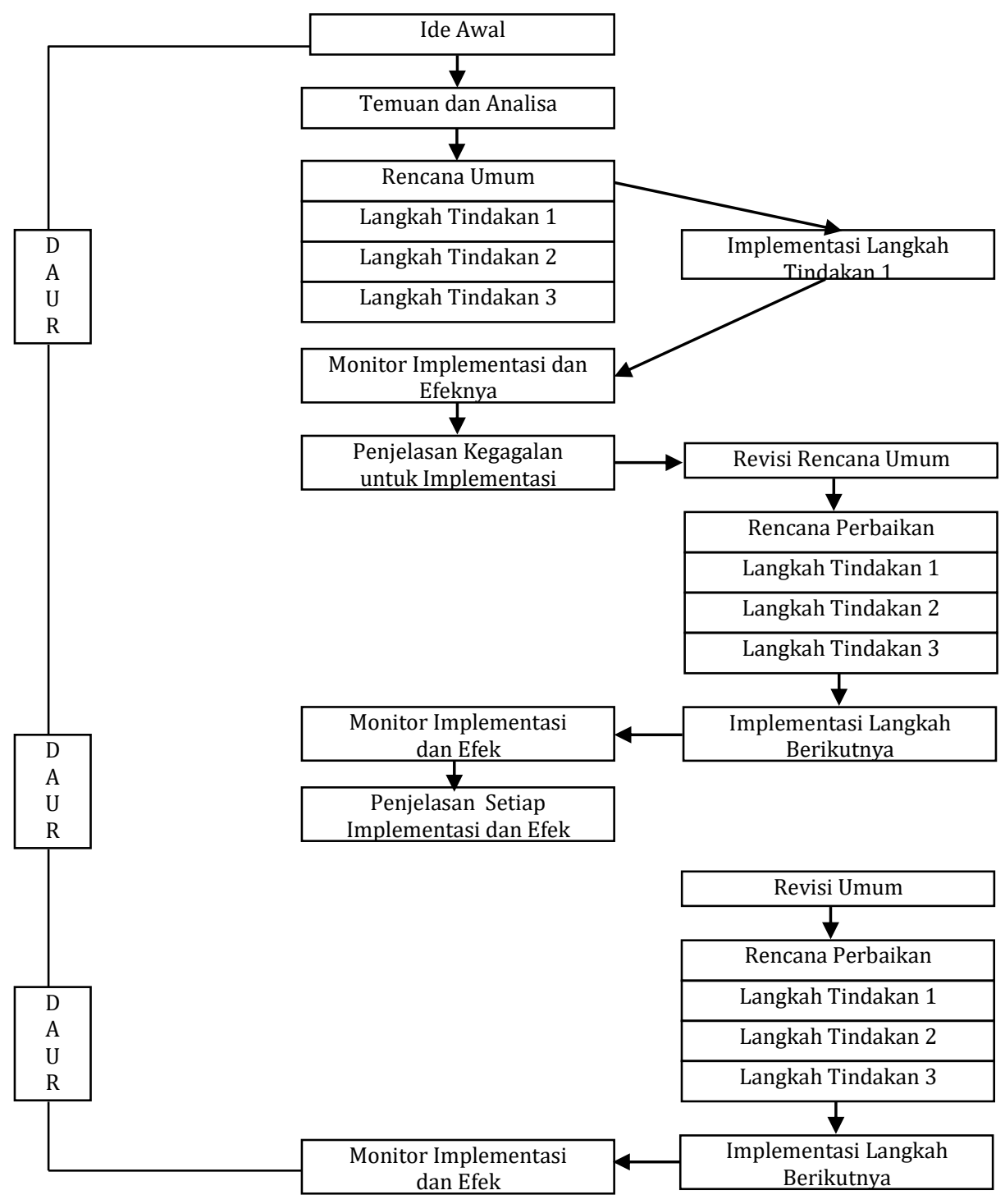

Gambar 1. Desain Penelitian Tindakan Model Ebbut

Desain yang diberikan oleh Ebbut di atas siklusnya sampai 3. Namun dalam penelitian ini hanya digunakan dua siklus dan mengikuti model penelitian yang diberikan oleh Direktorat Jendral Peningkatan Mutu Pendidik dan Tenaga Kependidikan (2008) yang langkah-langkahnya dapat dilihat pada gambar berikut.

Penelitian ini dilaksanakan di kepada guru-guru SD Negeri 1 Temesi yang berjumlah 9 orang. Sedangkan Objeknya adalah peningkatan kinerja guru-guru dalam melaksanakan proses pembelajaran. Metode yang digunakan untuk mengumpulkan data adalah mengikuti langkah-langkah yang digunakan dalam supervisi akademik. Untuk menguji hipotesis penelitian ini dicocokan dengan indikator-indikator keberhasilan penelitian yaitu pengisian lembar observasi penelitian tugas guru. Apabila indikator indikator keberhasilan belum tercapai, maka penelitian ini belum bisa dikatakan berhasil ,dan dilanjutkan ke proses berikutnya, apabila hasil yang diperoleh sudah memenuhi kriteria keberhasilan penelitian, maka penelitian ini tidak dilanjutkan ke siklus berikutnya.

\section{Hasil dan Pembahasan}

Penelitian Deskripsi yang dapat disampaikan untuk perolehan data awal sebagai indikator yang dituntut yaitu minimal guru mampu mencapai ketuntasan belajar dengan nilai sama atau melebihi Ketuntasan namun pada data awal guru-guru SD Negeri 1 Temesi masih jauh dari harapan. Indikator 
keberhasilan pada penelitian ini yaitu guru-guru diharapkan mampu meraih nilai kuantitatif $A$ atau ratarata berada pada rentang antara 86-100. Data yang diperoleh menunjukkan nilai klaksikal yang diperoleh sebesar 708 dengan rata-rata hanya mencapai 75,00. Rata-rata yang diperoleh berada antara rentang 6675 ini artinya nilai kuantitatif yang diperoleh adalah $\mathrm{C}$ (Cukup). Pada data ini tidak ada guru yang mendapat nilai kuntitatif A, 5 Guru mendapat tergolong nilai kuantitatif B, 4 orang guru memperoleh nilai C dan sisanya memperoleh nilai D. Data tersebut menunjukkan rendahnya kemampuan guru SD Negeri 1 Temesi dalam melaksanakan pembelajaran. Kekurangan yang ada adalah akibat proses pembelajaran yang dilakukan oleh guru masih bersifat konvensional. Kelebihannya adalah peneliti sebagai pengawas telah giat melakukan supervisi secara maksimal.

Perkembangan kinerja guru pada siklus I adalah ada 1 orang guru yang memperoleh niali A, 6 orang guru yang memperoleh nilai B, dan sisanya 2 orang memperoleh nilai C. Nilai klasikal yang diperoleh adalah 750 dengan rata-rata mencapai 83,33 dengan kualifikasi B yang berada pada rentand 7685. Data tersebut menunjukkan nilai yang diperoleh sudah mengalami peningkatan namun belum maksimal dan perlu dilanjutkan dengan tndakan berikutnya.

Perkembangan kemampuan guru pada siklus II adalah mengalami peningkatan yang signifikan. Ada 4 guru yang memperoleh kualifikasi nilai A, dan sisanya 5 orang guru memperoleh kualifikasi nilai B. Nilai klaksikal yang diperoleh mencapai 823 dengan rata-rata 91,44 dengan kualifikasi nilai A. Data tersebut menunjukkan proses pembelajaran sudah berjalan maksimal karena semua guru sudah mampu mencapai kriteria usulan kinerja yang diharapkan yaitu nilai rata-rata 86,00 dengan kualifikasi klaksikan antara rentang 86-100 atau A (amat baik) sehingga penelitian ini tidak perlu dilanjutkan dengan tndakan berikutnya.

Gambaran hasil penelitian ini dapat digambarkan pada gambar histogram berikut.

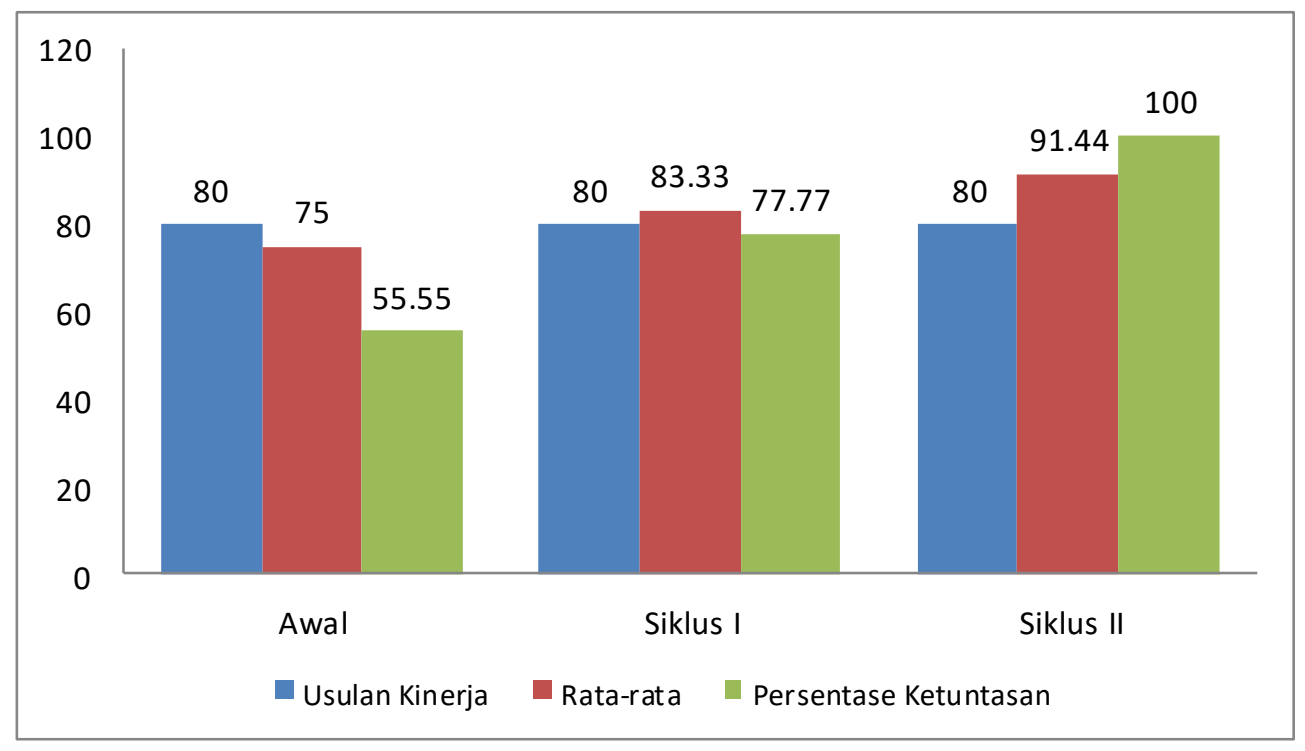

Gambar 1. Hasil Penilaian Kinerja Guru Melaksanakan Proses Pembelajaran yang berkualitas dari awal, siklus I, Siklus II

Berdasarkan hasil penelitian tersebut dapat dikatakan bahwa dengan penerapan supervisi akademik secara optimal akan mampu meningkatkan kinerja guru dalam proses pembelajaran. Dengan adanya bimbingan dan penegawan oleh kepala sekolah akan membantu guru untuk lebih nyaman menyampaikan masalah yang dihadapi dan mencari solusinya bersama-sama. Tugas utama seorang kepala sekolah adalah mengawasi dan sekaligus meningkatkan kemampuan guru dalam melaksanakan proses pembelajaran (Hadi, 2019; Widiyastuti \& Arikunto, 2015). Sebagai kepala sekolah harus betulbetul memperhatikan apakah pembelajaran itu berkualitas atau tidak, apabila tidak berkualitas maka hal tersebut akan berbahaya terhadap mutu pendidikan. Oleh karenanya sebagai seorang Kepala Sekolah mesti giat untuk melakukan supervisi. Supervisi akademik menitik beratkan pengamatan pada masalah yang langsung berada dalam lingkup pembelajaran yang dilakukan guru untuk membantu siswa ketika sedang dalam proses belajar sehingga semakin sering kepala sekolah melakukan supervisi akademik, maka akan terdapat peningkatan secara signifikan kualitas kinerja guru dalam proses pembelajaran (Hadi, 2019). 
Selain supervise yang dilkukan oleh kepala sekolah kinerja guru dalam proses pembelajaran juga dipengaruhi oleh model pembelajaran yang digunkan yaitu model STAD. dengan adanya model ini maka proses pembelajaran siswa akan lebih baik, karena siswa belajar dengan aktif di dalam kelompoknya. Proses pembelajaran yang tidak membedakan suku, agama dan prestasi siswa sangat membatu siswa menumbuhkan rasa kerja sama. STAD merupakah salah satu model pembelajaran yang berguna untuk menumbuhkan kemampuan kerjasama, kreatif, berpikir kritis dan ada kemampuan untuk membantu teman serta merupakan pembelajaran kooperatif yang sangat sederhana (HM, 2019; Israil, 2019; Purba, 2018). Beberapa penelitian yang sudah dilakukan antara lain: Hasil penelitian yang dilakukan oleh (Darmayanti, 2018) dengan judul Pengaruh Model Pembelajaran STAD berbasis Portofolio terhadap Kompetensi Pengetahuan Matematika. Berdasarkan hasil penelitian dapat disimpulkan bahwa terdapat pengaruh model pembelajaran STAD berbasis portofolio terhadap kompetensi pengetahuan matematika pada siswa kelas V SD Negeri 1 Ubud tahun pelajaran 2017/2018. Berdasarkan hasil penelitian disarankan bahwa hasil penelitian ini dapat dijadikan sebagai kajian yang relevan khususnya sebagai penunjang penelitian selanjutnya mengenai model pembelajaran STAD berbasis portofolio. Selanjutnya penelitian yang dilakukan oleh (Sudana, 2017) dengan judul penerapan model pembelajaran kooperatif tipe STAD untuk meningkatkan hasil belajar IPA. Hasil penelitian menunjukkan bahwa penerapan model pembelajaran Tipe STAD dapat meningatkan hasil belajar IPA siswa kelas IV A semester ganjil Tahun Pelajaran 2016/2017 di SD No. 3 Dalung.

Hasil peneitian ini sejalan dengan penelitian yang dilakuken oleh (Yuliana et al., 2017) yang menyatakan bahwa model pembelajaran tipe STAD dengan metode mnemonik berpegaruh positif dan signifikan terhadap hasil belajar siswa. Penelitian yang dilakukan oleh (HM, 2019) menyatakan bahwa model Student Team Achievement Division dapat meningkatkan motivasi dan hasil belajar matematika siswa kelas V di SD Negeri Ledok 07 Salatiga semester genap tahun 2018/2019. Kemudian penelitian yang dilakukan oleh Penelitian lain yang dilakukan oleh (Budiyono \& Ngumarno, 2019) menyatakan bahwa penerapan STAD (Student Team Achievement Division) terdapat peningkatan hasil belajar yang signifikan. Penelitian lain yang dilakukan oleh (Israil, 2019) menyatakan bahwa model pembelajaran cooperatif learning tipe STAD dalam pembelajaran IPA pada materi unsur, senyawa, dan campuran dapat meningkatkan motivasi belajar siswa yang ditunjukkan dengan adanya peningkatan persentase ketuntasan belajar pada siklus II di kelas VII SMP Negeri 1 Kayangan. Penelitian yang dilakukan oleh (Murjianti et al., 2018) menyatakan bahwa implementasi STAD menggunakan video sumber daya alam dapat meningkatkan motivasi siswa dengan hasil penelitian menunjukkan skor rata-rata $83,97 \%$, dan persentase kriteria minimal menunjukkan 80.

\section{Simpulan Dan Saran}

Berdasarkan hasil penelitian yang telah dilakukan, dapat disimpulkan bahwa: penerapan model pembelajaran kooperatif tipe Student Team Achievement Devision (STAD) dan supervisi akademik secara efektif dapat meningkatkan kinerja guru-guru dalam melaksanakan proses pembelajaran di SD Negeri 1 Temesi Semester II Tahun Pelajaran 2018/2019. Merujuk pada simpulan di atas, dapat diajukan beberapa saran yakni guru disarankan untuk selalu meningkatkan kemampuan dalam melaksanakan proses pembelajarannya, sehingga penyampaian materi pembelajaran kepada siswa dapat menyenangkan dan bermakna, kepala sekolah disarankan untuk melaksanakan supervisi secara berkelanjutan sehingga mampu memperbaiki dan memberikan masukan kepada guru-guru terutama dalam proses pelaksanaan pembelajaran di kelas, peneliti lain disarankan untuk mengembangkan penelitian ini dan menggunakan penelitian ini sebagai rujukan dalam melaksanakan penelitian selanjutnya.

\section{Daftar Rujukan}

Darmayanti, N.P.D, dkk. 2018 Pengaruh Model Pembelajaran STAD berbasis Portofolio terhadap Kompetensi Pengetahuan Matematika. International Journal of Elementary Educations Volume 2 Nomor 3. http://dx.doi.org/10.23887/ijee.v2i3.15962

Firmansyah, Dani. 2016. Pengaruh Strategi Pembelajaran Dan Minat Belajar Terhadap Hasil Belajar Matematika. Jurnal Pendidikan Unsika Volume 3 Nomor 1, Maret 2015. https://journal.unsika.ac.id/index.php/judika/article/view/199

Hadi, S. (2019). Supervisi Akademik Kunjungan Kelas Oleh Kepala Sekolah Dalam Rangka Meningkatkan Kinerja Guru ( Studi Kasus Di SMP NW Jerua ). Fondatia : Jurnal Pendidikan Dasar, 3(2), 114-135. https://doi.org/https://doi.org/10.36088/fondatia.v3i2.371

HM, M. (2019). The application of STAD-Cooperative Learning Model: Efforts to increase motivation and 
Learning Outcomes of students in Class 5 SD N 07 Ledok Salatiga in Mathematics subjecth in Folding Symmetry and Rotating Symmetry topics. Mudarrisa: Jurnal Kajian Pendidikan Islam, 11(2). https://doi.org/https://doi.org/10.18326/mdr.v11i2.114-135

Israil, I. (2019). Implementasi Model Pembelajaran Cooperative Learning Tipe STAD untuk Meningkatkan Motivasi Belajar Siswa dalam Pembelajaran IPA di SMP Negeri 1 Kayangan. Jurnal Kependidikan: Jurnal Hasil Penelitian Dan Kajian Kepustakaan Di Bidang Pendidikan, Pengajaran Dan Pembelajaran, 5(2), 117-123. https://doi.org/10.33394/jk.v5i2.1807

Karsiyem dan Muhammad Nur Wangid. 2015 Pelaksanaan Supervisi Akademik Dalam Peningkatan Kinerja Guru Sekolah Dasar Gugus III Sentolo Kulon Progo. Jurnal Akuntabilitas Manajemen Pendidikan Volume 3 Nomor 2. https://doi.org/10.21831/amp.v3i2.6337

Nurkholis. 2013. Pendidikan Dalam Upaya Memajukan Teknologi . Jurnal Kependidikan, Vol. 1 No. 1 Nopember 2013. https://doi.org/10.24090/jk.v1i1.530

Purba, I. S. B. (2018). Improving Fourth Grade Natural Science Learning Outcomes With Type Student Team Achievement Division (Stad) Cooperative Model. Journal of Elementary Education, 2(2). https://doi.org/https://doi.org/10.22460/pej.v2i2.1006

Sholichah, Aas Siti . 2018. Teori-Teori Pendidikan Dalam Al-Qur'an . Jurnal Edukasi Islami Jurnal Pendidikan Islam Vol. 07/No.1, April 2018. http://dx.doi.org/10.30868/ei.v7i01.209

Sudana, I. P. A., \& Wesnawa, I. G. A. (2017). Penerapan Model Pembelajaran Kooperatif Tipe STAD Untuk Meningkatkan Hasil Belajar IPA. Jurnal Ilmiah Sekolah Dasar, 1(1), 1-8. http://dx.doi.org/10.23887/jisd.v1i1.10128

Sukidin, dkk., 2002. Manajemen Penelitian Tindakan Kelas. Jakarta: Insan. Cendekia.

Sutrisno. 2016. Berbagai Pendekatan Dalam Pendidikan Nilai Dan Pendidikan Kewarganegaraan . Jurnal Dimensi Pendidikan dan Pembelajaran Vol.5 Januari 2016. DOI : 10.24269/dpp.v4i1.56

Suwartini, Erni Agustina. 2017. Supervisi Akademik Kepala Sekolah, Profesionalisme Guru Dan Mutu Pendidikan. Jurnal Administrasi Pendidikan Vol.XXIV No.2 Oktober 2017. https://doi.org/10.17509/jap.v24i2.8294

Widiyastuti, M., \& Arikunto, S. (2015). Dinamika Kepemimpinan Kepala Sekolah Dalam Mengembangkan Sekolah Efektif Di SD Kanisius Kadirojo, Sengkan, Duwet. Jurnal Akuntabilitas Manajemen Pendidikan, 3(1), 82-96. https://doi.org/10.21831/amp.v3i1.6272

Widodo, Heri. 2015. Potret Pendidikan Di Indonesia Dan Kesiapannya Dalam Menghadapi Masyarakat Ekonomi Asia (Mea) . Jurnal Cendekia Vol. 13 No. 2, Juli - Desember 2015. https://doi.org/10.21154/cendekia.v13i2.250 